\title{
Pyropheophorbide-Fullerene Dyad: Synthesis and Photochemical Properties
}

\author{
Alexander Yu. Rybkin, ${ }^{a @ ~ A l e x a n d r a ~ Y u . ~ B e l i k, ~}{ }^{a}$ Pavel A. Tarakanov, ${ }^{\mathrm{a}, \mathrm{c}}$ \\ Kamil R. Taziev, ${ }^{\mathrm{b}, \mathrm{a}}$ Alexei V. Kozlov, ${ }^{a}$ Nikolay S. Goryachev, ${ }^{\mathrm{a}, \mathrm{b}}$ Ilya V. Sulimenkov, ${ }^{\mathrm{d}}$

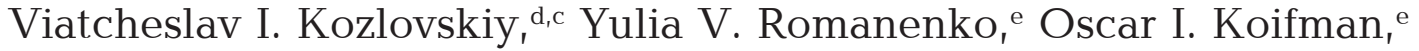 \\ and Alexander I. Kotelnikov ${ }^{\mathrm{a}, \mathrm{b}}$
}

\author{
anstitute of Problems of Chemical Physics RAS, 142432 Chernogolovka, Russia \\ ${ }^{\mathrm{b}}$ Lomonosov Moscow State University, 119991 Moscow, Russia \\ 'Institute of Physiologically Active Compounds RAS, 142432 Chernogolovka, Russia \\ ${ }^{\mathrm{d}}$ Talrose Institute for Energy Problems of Chemical Physics (Branch) RAS, 142432 Chernogolovka, Russia \\ 'Ivanovo State University of Chemistry and Technology, 153000 Ivanovo, Russia \\ ${ }^{\circledR}$ Corresponding author e-mail: alryb@icp.ac.ru
}

\begin{abstract}
The methylpyropheophorbide-fullerene[60] dyad was synthesized by 1,3-dipolar cycloadditions of the corresponding azomethine ylide to $C_{60}$ (Prato reaction). Using the mass spectrometric method with soft matrix-activated ionization it was possible to achieve a significant reduction in fragmentation processes by the retro-Diels-Alder reaction, which allows to reliably detect the presence of polyadducts of azomethine ylide cycloadditions to fullerene. The use of gel permeation chromatography under conditions of weakening of the intermolecular $\pi-\pi$ interaction between methylpyropheophorbide and fullerene moieties makes it possible to effectively separate mixed products with $\sim 1.5$ fold difference in molecular weight. It has been shown that the fluorescence of the dyad is quenched more than 5000 times (compared to the native dye). The singlet oxygen quantum yield of the dyad is 360 times less than that for the native methylpyropheophorbide a, however, its efficiency of superoxide generation increases by 18.5 times. The obtained result agrees well with the previously reported mechanism of relaxation of the excited state of the dyad through a charge-separated state, which can lead to the formation of superoxide. The observed effects indicate a change in the mechanism of photodynamic activity from type II (generation of singlet oxygen) for the native dye to type I (generation of superoxide) for the dyad, which shows a promising method of creation of highly efficient photosensitizers based on similar dye-fullerene[60] dyads.
\end{abstract}

Keywords: Pyropheophorbide, fullerene derivatives, fluorescence quantum yield, photochemical activity, singlet oxygen, mass spectrometry, matrix-assisted ionization.

\section{Аиада пирофеофорбиА-фуллерен: синтез и оценка фотохимических свойств}
А. Ю. Рыбкин, ${ }^{a}$ А. Ю. Белик, ${ }^{a}$ П. А. Тараканов, ${ }^{a, c}$ К. Р. Тазиев, ${ }_{1}^{\text {b,a }}$ А. В. Козлов, ${ }^{a}$ Н. С. Горячев, ${ }^{\mathrm{a}, \mathrm{b}}$ И. В. Сулименков, ${ }^{\mathrm{d}}$ В. И. Козловский, ${ }^{\mathrm{d}, \mathrm{c}}$ Ю. В. Романенко, ${ }^{\mathrm{e}}$ О. И. Койфрман, ${ }^{\text {e А. И. Котельников }}{ }^{\mathrm{a}, \mathrm{b}}$

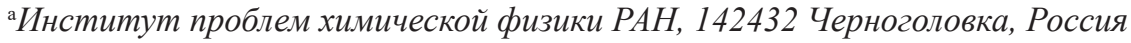

${ }^{\mathrm{b}}$ Московский государственный университет им. М.В. Ломоносова, 119991 Москва, Россия

'Институт физиологически активных веществ РАН, 142432 Черноголовка, Россия

${ }^{\mathrm{d}}$ Филиал института энергетических проблем химической физики им. В.Л. Тальрозе РАН, 142432 Черноголовка,

Россия

${ }^{\mathrm{e}}$ Ивановский государственный химико-технологический университет, 153000 Иваново, Россия

${ }^{\circledR}$ E-mail: alryb@icp.ac.ru
} 
Синтезирована диада метилпирофеофорбид-фуллерен путем 1,3-диполярного присоединения соответствующегго азометиниллида к фуллерену (реакция Прато). Использование метода мягкой матрично-активированной ионизации исследуемых соединений при масс-спектрометрических измерениях позволило добиться значительного снижения процессов фрагментации путем реакиии ретро-Дильса-Альдера, что позволило надежно детектировать наличие продуктов полиприсоединения азометиниллида к фуллерену. Применение гель-проникающей хроматографии в условиях ослабления межмолекулярного л-л взаимодействия между метилпирофеофорбидным и фуллереновым фрагментами позволяет эффективно разделять смесевые продуктьл, обладающие 1.5 кратным отличием по молекулярной массе. Методами стационарной флуориметрии показано, что флуоресиенция диады потушена более чем в 5000 раз по сравнению с исходным красителем. Квантовый выход генерации синглетного кислорода диады меньше, чем у метилпирофеофорбида а в 360 раз, при этом ее эффективность генерации супероксид анион-радикала возрастает в 18.5 раз. Полученный результат хорошо согласуется с опубликованным ранее механизмом релаксации возбужденного состояния для данной диады через состояние с разделенными зарядами, которое способно приводить к образованию супероксид анион-радикала. Обнаруженные эффекты говорят об изменении механизма фотодинамической активности с II типа (генерации синглетного кислорода) у исходного красителя на I тип (генерации супероксида) для диады метилпирофеофорбид-фуллерен, что показывает перспективность создания высокоэффективных фотосенсибилизаторов на основе подобных диад фуллерен-краситель.

Ключевые слова: Пирофеофорбид, фуллерен, квантовый выход флуоресценции, фотохимическая активность, синглетный кислород, масс-спектрометрия, матрично-активированная ионизация.

\section{Introduction}

Currently, active work is underway to create photoactive structures based on fullerene-dye dyads for photovoltaics and a number of other applications..$^{[1,2]}$ These dyads are of particular interest for photodynamic therapy as photosensitizers, since fullerene $\mathrm{C}_{60}$ has extremely high photoactivity - under light excitation it is capable of passing to an excited triplet state with almost $100 \%$ quantum yield ${ }^{[3,4]}$ and effectively generate reactive oxygen species (ROS).

According to the mechanism of photodynamic action, photosensitizers are divided into two main categories: type I (generation of superoxide by the mechanism $\mathrm{FS}^{*}+$ $\mathrm{O}_{2}=\mathrm{FS}^{+}+\mathrm{O}_{2}^{-*}$ ) and type II (generation of singlet oxygen by the mechanism $\left.\mathrm{FS}^{*}+\mathrm{O}_{2}=\mathrm{FS}+{ }^{1} \mathrm{O}_{2}\right) \cdot{ }^{[5,6]}$ The vast majority of photosensitizers that are used in clinical practice generate ROS according to type II mechanism. The creation of highly efficient photosensitizers that generate ROS by pathway I is of considerable interest since it is expected that they should be more effective in some cases, for example, against hypoxic tumors. ${ }^{[7]}$

We have previously created dyads based on fullerene and dyes fluorescein, ${ }^{[8]}$ ruboxy ${ }^{[9]}$ and chlorin, ${ }^{[10]}$ which showed the high efficiency of ROS generation. For example, a tenfold increase in the superoxide generation efficiency by a fullerene-chlorin dyad in an aqueous solution (compared to a free chlorin) was shown. ${ }^{[10]}$ Superoxide generation upon photoexcitation is due to the presence of a chargeseparation state in dyad, ${ }^{[11]}$ which leads to the first pathway of ROS generation.

However, for the dyads, in which fullerene spheroid contains a smaller amount of $s p^{2}$ hybrid carbon atoms (due to the addends directly attached to the fullerene core), there is an increase in the LUMO energy ${ }^{[12-16]}$ and the triplet level energy of the excited state, ${ }^{[17,18]}$ which cause a decrease in both its electron affinity and its quantum yield of singlet oxygen generation. Thus, each new addend that attached directly to fullerene core decreases significantly the quantum yield of ROS formed through both paths I and II.

The main goal of the present work was the study of the photophysical properties and photochemical activity of the fullerene-dye dyad, in which the symmetry of the fullerene core is minimally distorted. A dyad in which the dye methylpyropheophorbide $a$ is attached directly to the fullerene by 1,3-dipolar cycloadditions of the corresponding azomethine ylide to $\mathrm{C}_{60}$ (Prato reaction) was chosen as a model of such structure. Similar dyads have already been described in a number of works, ${ }^{[19-21]}$ but it was assumed that they will be used in photovoltaics and the efficiency ROS generation was not evaluated. In the present paper, the ability of the pyropheophorbid-fullerene dyad to generate ROS through I and II pathways is compared for the first time.

\section{Experimental}

Synthesis of methylpyropheophorbide a was carried out according to the previously described method. ${ }^{[22]}$ Product yield: $86.4 \%$. MC (ESI) $m / z 548[\mathrm{M}]^{+}$, calcd for $\mathrm{C}_{34} \mathrm{H}_{36} \mathrm{~N}_{4} \mathrm{O}_{3} 548$. UVVis $\left(\mathrm{C}_{6} \mathrm{H}_{5} \mathrm{~N}\right) \lambda$ (relative absorption) $\mathrm{nm}: 669(0.42), 611(0.05), 539$ (0.05), 509 (0.07), 415 (1.00). ${ }^{1} \mathrm{H}$ NMR (200 MHz, $\left.\mathrm{CDCl}_{3}\right) \delta_{\mathrm{H}} \mathrm{ppm:}$ $9.43(1 \mathrm{H}, \mathrm{s}, 10-\mathrm{CH}), 9.31(1 \mathrm{H}, \mathrm{s}, 5-\mathrm{CH}), 8.48(1 \mathrm{H}, \mathrm{s}, 20-\mathrm{CH}), 7.93$ $(1 \mathrm{H}, \mathrm{dd} J=17.9,11.6 \mathrm{~Hz}, 3(1)-\mathrm{CH}), 6.21(1 \mathrm{H}, \mathrm{d} J=17.9 \mathrm{~Hz}, 3(2)-$ $\mathrm{CH}$ trans), $6.10(1 \mathrm{H}, \mathrm{d} J=11.6 \mathrm{~Hz}, 3(2)-\mathrm{CH}$ cis $), 5.12(2 \mathrm{H}, \mathrm{q} J=$ $\left.20,2 \mathrm{~Hz}, 13-\mathrm{CH}_{2}\right), 4.43(1 \mathrm{H}, \mathrm{m}, 18-\mathrm{CH}), 4.22(1 \mathrm{H}, \mathrm{m}, 17-\mathrm{CH}), 3.59$ $\left(8 \mathrm{H}, \mathrm{m}, 2(1)-\mathrm{CH}_{3}, 8(1)-\mathrm{CH}_{2}, 12(1)-\mathrm{CH}_{3}\right), 3.34\left(3 \mathrm{H}, \mathrm{s}, 17(3)-\mathrm{OCH}_{3}\right)$ $3.16\left(3 \mathrm{H}, \mathrm{s}, 7(1)-\mathrm{CH}_{3}\right), 2.58\left(2 \mathrm{H}, \mathrm{m}, 17(1)-\mathrm{CH}_{2}\right), 2.23(2 \mathrm{H}, \mathrm{m}$, $\left.17(2)-\mathrm{CH}_{2}\right), 1.74\left(3 \mathrm{H}, \mathrm{d} J=7.2 \mathrm{~Hz}, 18(1)-\mathrm{CH}_{3}\right), 1.62(\mathrm{t} J=7.6 \mathrm{~Hz}$, $\left.8(2)-\mathrm{CH}_{3}\right),-1.76(1.4 \mathrm{H}, \mathrm{s}, 21,23-\mathrm{NH})$.

Synthesis of methylpyropheophorbide $d$ was carried out according to the previously described method. ${ }^{[23]}$ The product was chromatographed on silica gel, eluent $0.5 \%$ methanol solution in methylene chloride. Product yield: $61.7 \%$. MS (ESI) $\mathrm{m} / \mathrm{z}$ $551[\mathrm{M}+\mathrm{H}]^{+}$, calcd for $\mathrm{C}_{33} \mathrm{H}_{35} \mathrm{~N}_{4} \mathrm{O}_{4} 551$. UV-Vis $\left(\mathrm{CH}_{2} \mathrm{Cl}_{2}\right) \lambda$ (relative absorption) nm: $697.8(0.75), 637.3(0.09), 557.7(0.16), 523.8(0.14)$, 429.4 (1.00), 389.2 (0.85). ${ }^{1} \mathrm{H}$ NMR $\left(200 \mathrm{MHz}, \mathrm{CDCl}_{3}\right) \delta_{\mathrm{H}} \mathrm{ppm}$ : 
$11.41(1 \mathrm{H}, \mathrm{s}, 3(1)-\mathrm{CH}), 10.12(1 \mathrm{H}, \mathrm{s}, 10-\mathrm{CH}), 9.43(1 \mathrm{H}, \mathrm{s}, 5-\mathrm{CH})$, $8.75(1 \mathrm{H}, \mathrm{s}, 20-\mathrm{CH}), 5.18\left(2 \mathrm{H}, \mathrm{q} J=20.3 \mathrm{~Hz}, 13-\mathrm{CH}_{2}\right), 4.49(1 \mathrm{H}$, $\mathrm{m}, 18-\mathrm{CH}), 4.30(1 \mathrm{H}, \mathrm{m}, 17-\mathrm{CH}), 3.67\left(3 \mathrm{H}, \mathrm{s}, 2(1)-\mathrm{CH}_{3}\right), 3.57(8 \mathrm{H}$, $\left.\left.\mathrm{m}, 12(1)-\mathrm{CH}_{3}\right), 8(1)-\mathrm{CH}_{2}, 17(3)-\mathrm{OCH}_{3}\right), 3.16\left(3 \mathrm{H}, \mathrm{s}, 7(1)-\mathrm{CH}_{3}\right)$, $2.59\left(2 \mathrm{H}, \mathrm{m}, 17(1)-\mathrm{CH}_{2}\right), 2.24\left(2 \mathrm{H}, \mathrm{m}, 17(2)-\mathrm{CH}_{2}\right), 1.78(3 \mathrm{H}, \mathrm{d}$ $\left.J=7.2 \mathrm{~Hz}, 18(1)-\mathrm{CH}_{3}\right), 1.59\left(3 \mathrm{H}, \mathrm{t} J=7.6 \mathrm{~Hz}, 8(2)-\mathrm{CH}_{3}\right),-0.36$ (0.5H, br.s, 21-NH), $-2.26(0.7 \mathrm{H}$, br.s, $23-\mathrm{NH})$.

Synthesis of dyad fullerene-methylpyropheophorbide by Prato reaction was carried out according to the previously described method ${ }^{[24]}$ with some changes. Methylpyropheophorbide $d(0.167 \mathrm{~g}, 0.3 \mathrm{mM})$, fullerene $\mathrm{C}_{60}(1.506 \mathrm{~g}, 2.09 \mathrm{mM})$ and sarcosine $(0.135 \mathrm{~g}, 1.52 \mathrm{mM})$ were dissolved in $70 \mathrm{ml}$ of $o$-dichlorobenzene. The resulting solution was subjected to ultrasonic irradiation then refluxed and stirring under an inert atmosphere for 24 hours. After completion of the reaction, the solvent was removed under vacuum, the dry residue was dissolved in $500 \mathrm{ml}$ of a $30 \%$ solution of trifluoroacetic acid in chloroform and filtered through a glass filter. Next, the filtered solution was evaporated, the resulting dry residue was dissolved in pyridine. Pyridine solution of the reaction mass $(1 \mathrm{mg} / \mathrm{ml})$ was subjected to gel permeation chromatography using cross-linked polystyrene (Bio-Beads S-X1) as the stationary phase. Product yield: $0.132 \mathrm{mg}(33 \%) .{ }^{1} \mathrm{H}$ NMR $\left(500 \mathrm{MHz}, \mathrm{CDCl}_{3}\right)$ $\delta_{\mathrm{H}}$ ppm: 11.72, $9.94(1 \mathrm{H}$, br.m, 5-CH), $9.78(1 \mathrm{H}$, br.m, 10-CH), $8.91,8.85$ (1H, br.s, 10-CH), 6.81, 6.37 (1H, br.s, 2'-CH), 5.41-5.03 $\left(3 \mathrm{H}, \mathrm{m}, 5\right.$ '- $\left.\mathrm{CH}_{2}, 13(2)-\mathrm{CH}_{2}\right), 4.62-4.49\left(2 \mathrm{H}, \mathrm{m}, 5\right.$ ' $\left.-\mathrm{CH}_{2}, 18-\mathrm{CH}\right)$, 4.39-4.28 (1H, m, 17-CH), 3.74-3.38 (14H, m, 2(1)-CH3, 8(1)- $\mathrm{CH}_{2}$, $\left.12(1)-\mathrm{CH}_{3}, 17(4)-\mathrm{OCH}_{3}, 7(1)-\mathrm{CH}_{3}\right), 2.75-2.17\left(4 \mathrm{H}, \mathrm{m}, 17(1)-\mathrm{CH}_{2}\right.$, $\left.17(2)-\mathrm{CH}_{2}\right), 1.88-1.79\left(3 \mathrm{H}, \mathrm{m}, 18(2)-\mathrm{CH}_{3}\right), 1.69-1.55(3 \mathrm{H}, \mathrm{m}, 8(2)-$ $\left.\mathrm{CH}_{3}\right),-1.95,-2.07(1.5 \mathrm{H}, \mathrm{s}, 21,23-\mathrm{NH})$. High resolution MS (HR MAI) $m / z 1298.3143[\mathrm{M}+\mathrm{H}]^{+}$, calcd for $\mathrm{C}_{95} \mathrm{H}_{40} \mathrm{~N}_{5} \mathrm{O}_{3} 1298.3126$. UV-Vis $\left(\mathrm{C}_{6} \mathrm{H}_{5} \mathrm{~N}\right) \lambda(\lg \varepsilon) \mathrm{nm}$ : 662 (4.63), 506 (4.37), 419 (5.11).

\section{Matrix Activated Ionization Method (MAI)}

Mass spectra were acquired using the Exactive Orbitrap high resolution mass spectrometer (ThermoFisher Scientific, Germany). The sample solutions in the concentrated trifluoroacetic acid were mixed with a saturated solution of the matrix (Phthalonitrile) in acetonitrile in 1:1 ratio. The concentration of the sample in the prepared solution, according to our estimates, was $5 \mathrm{mkM}$. The solution was deposited to the thin metal wire. After the short drying at the ambient conditions this wire was introduced through the interface capillary of the mass spectrometer inside the mass spectrometric interface with 2 mbar buffer gas pressure. In this region ions desorbed from the wire were collected by an ion funnel and transferred through the skimmer to mass analyzer. The tip of the wire with the applied solution was located at $10 \mathrm{~mm}$ in front of the skimmer. The resolution of the mass spectrometer was about 15.000. The accuracy of $\mathrm{m} / \mathrm{z}$ values measurement was better than $5 \mathrm{ppm}$.

\section{Analysis of ROS Generation}

The photochemical reaction was performed in a $10 \times 10 \mathrm{~mm}$ quartz cuvette in a temperature-controlled cell at $20{ }^{\circ} \mathrm{C}$. The cuvette was lighted with a xenon $40 \mathrm{~mW}$ lamp through a system of optical filters $(\lambda>630 \mathrm{~nm})$. Generation of singlet oxygen under light irradiation was estimated using a probe 1,3-diphenylisobenzofuran. ${ }^{[25,26]}$ (DPBF) in pyridine by measuring the relative change in the optical density at $420 \mathrm{~nm}$. Generation of superoxide under light irradiation was estimated using a standard formazan assay by measuring the evolution of the optical density at $560 \mathrm{~nm} .^{[27]}$ All measurements of photochemical activity are presented in the form (average \pm standard error) according to the results of at least three experiments. To dissolve the dyad and the original dye methylpyropheophorbide $a$ into an aqueous medium, they were solubilized using polyvinylpyrrolidone (PVP, mol.weight $\sim 10000$ ). To do this, the dyad or dye was dissolved in pyridine; a solution of PVP in pyridine was added. Pyridine was removed on a rotary evaporator. The resulting dry film was dissolved in 3-5 ml of water using an ultrasonic bath, and then water was removed on a rotary evaporator to completely remove traces of pyridine. Water $(2-3 \mathrm{ml})$ was added to the flask with the film to obtain a ratio of $0.4 \mathrm{mM}$ dye (or dyad) per $10 \mathrm{mg} / \mathrm{ml}$ of PVP aqueous solution, and then the film was treated on the ultrasonic bath until completely dissolved. The resulting solution was again treated on the ultrasonic bath for 10 minutes and diluted to the desired concentration.

\section{Results and Discussion}

\section{Separation and Characterization of Reaction Products}

1,3-Dipolar cycloaddition reaction of azomethinylides to the fullerene core proceeds with low selectivity and leads to the formation of side polyadducts. The use of column liquid chromatography on silica gel to separate adducts of mono- and di-addition of azomethinylide derivatives of pyropheophorbide $a$ to fullerene, described in, ${ }^{[24]}$ proved ineffective. Only the thin-layer chromatography conditions used in this work could allow separating the resulting mixture $\mathbf{2}$ and $\mathbf{3}$. However, it was not possible to use this method for quantitative separation due to the close relative mobility of the components ( 2 and $\mathbf{3}$ ) transfer over the TLC plate. Gel permeation chromatography allows one to separate dyads from polyaddition products with high efficiency. ${ }^{[28]}$ However, due to the effective intermolecular $\pi-\pi$ donoracceptor interaction between the porphyrin-fullerene entities $^{[29]}$ in our case, additional restrictions are imposed on the maximum concentration in the final reaction mass of the conjugates $\mathbf{2}, \mathbf{3}$, as well as the content of the methylpyropheophorbide $d$ and fullerene and their side products, to prevent the formation of supramolecular aggregates of mixed composition under gel permeation chromatography. Thus, a sevenfold excess of fullerene and an increase in the reaction temperature led to a significant decrease of the starting methylpyropheophorbide $d$ and its side products in the final reaction mass. Dissolving the reaction mass in a $30 \%$ solution trifluoroacetic acid in chloroform followed by filtering allows to quantitatively separating from fullerene. Moreover, a dry product, evaporated on a rotary evaporator after contact with acid has better solubility in organic solvents compared to the one before the contact. The observed effect is most likely associated with the destruction of intermolecular interactions between the chlorin-fullerene entities - as a result of the protonation of the nitrogen atom as a tertiary amine, as well as intracyclic nitrogen atoms of chlorin macroheterocycle. Thus, gel permeation chromatography in pyridine leads to a quantitative separation of the reaction mass (with the concentration of the reaction mass of $1 \mathrm{mg} / \mathrm{ml}$ ) into three main fractions: triad 3, dyad 2 and unsubstituted fullerene with traces of chlorin. Unfortunately, a change in the synthesis conditions did not lead to an increase in the yield of the target monoaddition product $\mathbf{2}$, however, reducing the content of chlorin structures in the reaction products made it possible to avoid additional column liquid chromatography on silica gel. Thus, reaction mass obtained by the method ${ }^{[24]}$ in similar conditions does not allow to get adequate purity of the product 2 using gel permeation chromatography. 
Intens.
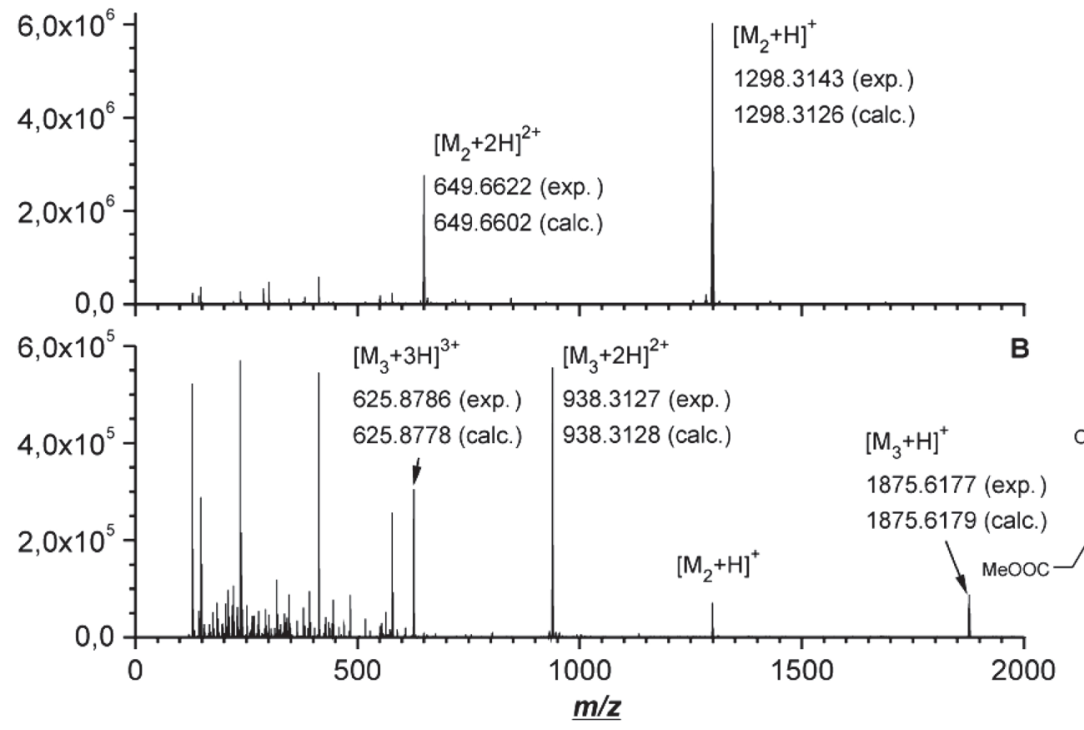

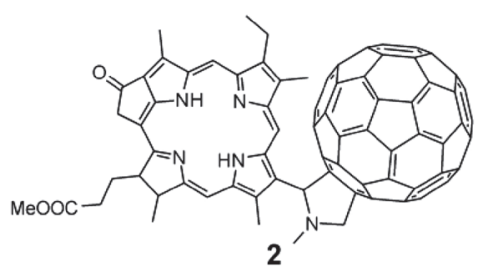

2

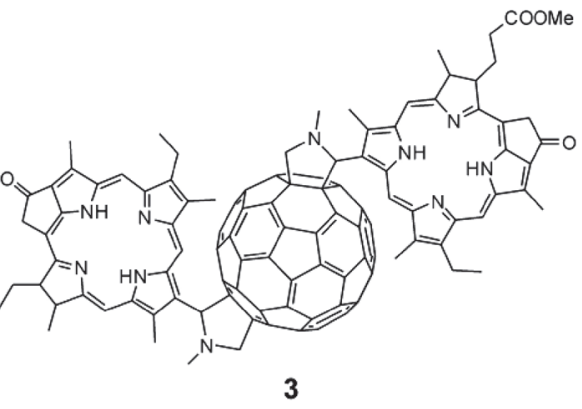

3

Figure 1. Mass spectra of fractions with gel permeation chromatography, obtained by the method of matrix activated ionization (MAI). A - fraction $N 2$, B - fraction $N 1$. The number of the fractions corresponds to their order of passing through the column.

In this case, even additional column liquid chromatography on silica gel leads to unpurified product $\mathbf{2}$, containing both methylpyropheophorbide $d$ itself and its chlorin derivatives side products, as evidenced by fluorescence and excitation spectra (Figure S6, 7).

As it can be seen from Figure 1, the main bi-product is the product 3; however, this compound was not detected using the MALDI ion source for mass-spectral analysis. This may be due to the inverse reaction (retro Diels-Alder), since such a reaction can be activated by an intensive ultraviolet radiation pulse used in the MALDI ion source. Using an electrospray ion source for mass-spectral analysis of samples is complicated by the poor solubility of our compounds. The samples were dissolved in the concentrated trifluoroacetic acid. Using an electrospray ion source these solutions must be diluted with a suitable solvent, such as acetonitrile or methanol, since a concentrated acid injection to an electrospray emitter can destroy the ion source. But under the dilution, the concentration of the dissolved sample decreases, and the sample can precipitate in the resulting diluted solution. Several years ago, an alternative ionization method was proposed - the so called matrix-activated ionization of samples under study ${ }^{[30]}$ (MAI). Using a modification of this method it was possible to reliably detect products 2 and $\mathbf{3}$. The mass spectra of the solutions of samples from two chromatographic fractions are presented in Figure 1. Analysis of the isotopic distributions of the detected ion peaks and accurate measurement of the ion $\mathrm{m} / \mathrm{z}$ values allowed to reliably identify the main registered ions. In the mass spectrum in Figure 1A one can see the intense peaks of protonated (singly and doubly charged) product 2 ions. In this mass spectrum there are no any "traces" of protonated product 3 ions. On the contrary, in the mass spectrum in Figure 1B, there are the intense protonated (single, double and triple charged) product 3 ions. The intensity of the singly charged product $\mathbf{2}$ ions in this mass spectrum is about $12 \%$ of the maximal intensity.

\section{Absorption and Fluorescence Spectra}

As can be seen from the absorption spectra (Figure 2A), a weak bathochromic shift of the Soret band is observed (from 417 to $419 \mathrm{~nm}$ ), which is typical for fullerene-dye dyads, however, for the peak in the $Q$-band region, the opposite hypsochromic shift is observed (from 673 to $662 \mathrm{~nm}$ ). The same picture is observed for similar dyads from paper. ${ }^{[20]}$

As we can observe in Figure 2B, the fluorescence of the dyad is completely quenched (more than 5000 times), the sensitivity of the device used does not allow it to be reliably detected (Figure 2B, in the inset) and calculate the fluorescence quantum yield. For similar dyads, which were previously presented, ${ }^{[20]}$ strong quenching of fluorescence was also reported (50-200 times), however, such a strong quenching for this dyad was observed for the first time. The residual fluorescence is probably associated with a small fraction of the impurity dye, which was not fully separated by the previously used purification methods, as it was already discussed above (Figures S6 and S7).

The high efficiency of fluorescence quenching of the dyad could be explained by the effective electron transfer from the excited state of the dye to the fullerene core. For a similar dyad, the formation of a charge-transfer state by flash photolysis was shown, ${ }^{[20]}$ which confirms the possibility of fluorescence quenching by the electron transfer mechanism.

On the contrary, the probability of fluorescence quenching by the Forster energy transfer mechanism is extremely small, as in the case of the fullerene-chlorin dyad described in our previous work, ${ }^{[10]}$ since the absorption of fullerene in the region of fluorescence of the dye is negligible.

As it can be seen from Figure 3A, combining dye and fullerene in one dyad leads to a significant reduction of singlet oxygen generation efficiency (360 times) compared with the native dye methylpyropheophorbide $a$. 

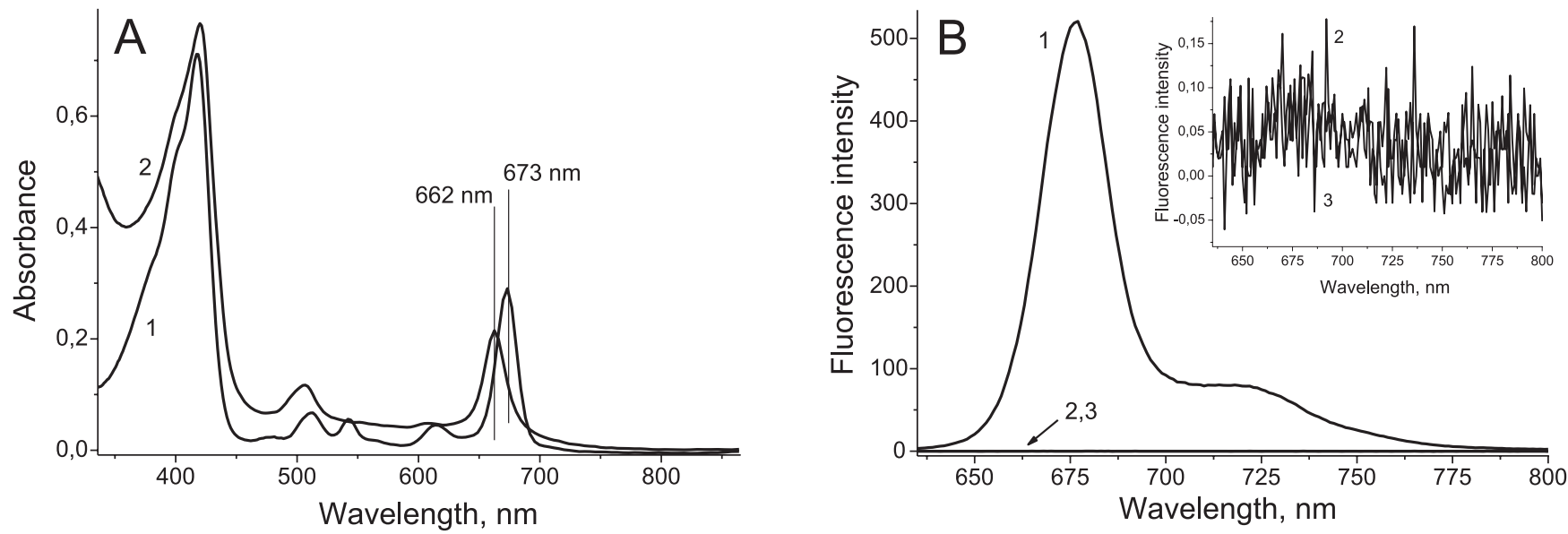

Figure 2. Absorption (A) and fluorescence spectra (B): methylpyropheophorbide $a 10^{-6} \mathrm{M}$ (1), dyad methylpyropheophorbide-fullerene (2) in pyridine and pure solvent (pyridine) (3). Fluorescence excitation wavelength is $415 \mathrm{~nm}$.
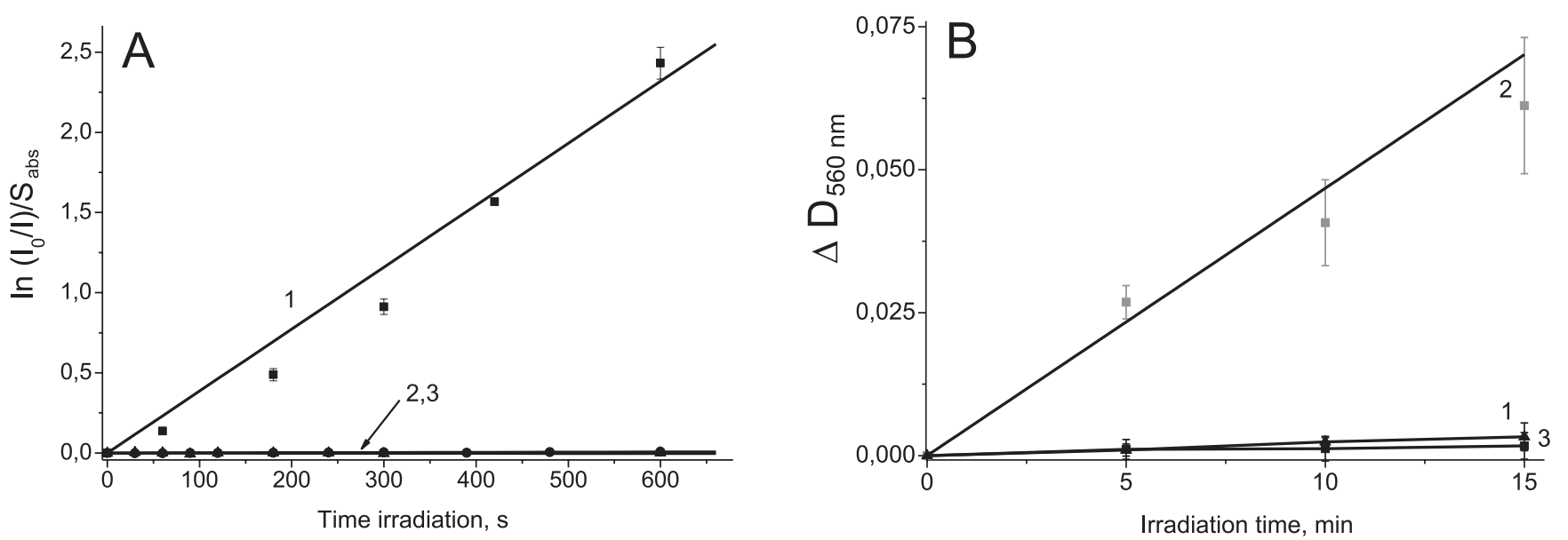

Figure 3. Kinetics of different ROS formation as a result of the photochemical reaction under visible light irradiation in the wavelength range of $\lambda>630 \mathrm{~nm}$ sensitized by dye methylpyropheophorbide $a$ (1), dyad methylpyropheophorbide-fullerene (2), control (3): A - singlet oxygen in pyridine, estimated by probe DPBF response and normalized to the absorption of the compound under study; $\mathrm{B}$ - superoxide in water, estimated by formazan method (dyad and methylpyropheophorbide $a$ dissolved in water using PVP).

The observed effect could be associated with the competitive way of fluorescence quenching not through the excited triplet state, but as a result of electron transfer and the formation of a long-lived charge-separation state, which was shown for an identical dyad in the papers, ${ }^{[19,20]}$ which could lead to a decreases of the quantum yield of singlet oxygen. At the same time, the superoxide generation efficiency of the dyad increases by 18.5 times compared with the native dye (Figure 3B). The obtained result is also in a good agreement with the assumption about the formation of a longlived charge-separated state in dyad 2 , which can lead to the formation of superoxide.

Thus, the observed effects indicate a change of the photodynamic activity mechanism from a type II reaction (singlet oxygen generation) for the original dye methylpyropheophorbide $a$ to the type I reaction (superoxide generation) for dyad 2.

In our next work we are going to study the electron transfer process in such structures, perform the optimization of a number of parameters (linker length between dye and fullerene, redox potentials of the dye and fullerene derivative), which will open the way for the creation of new highly efficient photosensitizers for photodynamic therapy.

The further development of the synthesis, separation and detection methods of such fullerene-dye dyads in order to obtain high purity compounds is also of key importance for the study of their biological activity and their medical applications.

Acknowledgement. The work was financially supported by the Russian Science Foundation (Grant №18-74-00128) and in the framework of the state task of the Ministry of Education and Science of the Russian Federation (Agreement No. 4.1929.2017/4.6).

\section{References}

1. Karmova F.M., Lebedeva V.S., Mironov A.F. Russ. J. Gen. Chem. 2016, 86, 2145. 
2. Tkachenko N.V., Efimov A., Lemmetyinen H. J. Porphyrins Phthalocyanines 2011, 15, 780 .

3. Koeppe R., Sariciftci N.S. Photochem. Photobiol. Sci. 2006, 5,1122 .

4. Arbogast J.W., Darmanyan A.P., Foote C.S., Diederich F.N., Whetten R.L., Rubin Y., Alvarez M.M., Anz S.J. J. Phys. Chem. 1991, 95, 11.

5. Baptista M.S., Cadet J., Di Mascio P., Ghogare A.A., Greer A., Hamblin M.R., Lorente C., Nunez S.C., Ribeiro M.S., Thomas A.H., Vignoni M., Yoshimura T.M. Photochem. Photobiol. 2017, 93, 912.

6. Dobson J., de Queiroz G.F., Golding J.P. Veterinary Journal 2018, 233, 8 .

7. $\quad$ Li Q., Huang C., Liu L., Hu R., Qu J. Cytometry Part A 2018, 93, 997.

8. Rybkin A.Y., Belik A.Y., Kraevaya O.A., Khakina E.A., Zhilenkov A.V., Goryachev N.S., Volyniuk D., Grazulevicius J.V., Troshin P.A., Kotelnikov A.I. Dyes Pigm. 2019, 160, 457.

9. Kotelnikov A.I., Rybkin A.Y., Khakina E.A., Kornev A.B., Barinov A.V., Goryachev N.S., Ivanchikhina A.V., Peregudov A.S., Martynenko V.M., Troshin P.A. Org. Biomol. Chem. 2013, 11, 4397.

10. Belik A.Y., Mikhailov P.A., Kraevaya O.A., Rybkin A.Y., Khakina E.A., Goryachev N.S., Usol'tseva L.I., Romanenko Y.V., Koifman O.I., Gushchina O.I., Mironov A.F., Troshin P.A., Kotel'nikov A.I. Dokl. Phys. Chem. 2017, 477, 222.

11. Holzwarth A.R., Katterle M., Müller M.G., Ma Y.-Z., Prokhorenko V. Pure Appl. Chem. 2007, 73, 469.

12. He D., Du X., Xiao Z., Ding L. Org. Lett. 2014, 16, 612.

13. Kang H., Cho C.H., Cho H.H., Kang T.E., Kim H.J., Kim K.H., Yoon S.C., Kim B.J. ACS Appl. Mater. Interfaces 2012, $4,110$.

14. Liu C., Xu L., Chi D., Li Y., Liu H., Wang J. ACS Appl. Mater. Interfaces 2013, 5, 1061.
15. Yoon S.C., Nam S.Y., Lee C., Kang H., Kim B.J., Kim P.S., Kim K.-H., Cho C.-H., Jung J. Chem. Mater. 2011, 23, 5090.

16. Han G.D., Collins W.R., Andrew T.L., Bulovië V., Swager T.M. Adv. Funct. Mater. 2013, 23, 3061.

17. Prat F., Stackow R., Bernstein R., Qian W., Rubin Y., Foote C.S. J. Phys. Chem. A 1999, 103, 7230.

18. Kordatos K., Ros T. Da, Prato M., Leach S., Land E.J., Bensasson R.V. Chem. Phys. Lett. 2001, 334, 221.

19. Tkachenko N.V., Rantala L., Tauber A.Y., Helaja J., Hynninen P.H., Lemmetyinen H. J. Am. Chem. Soc. 1999, 121, 9378.

20. Vehmanen V., Tkachenko N.V., Tauber A.Y., Hynninen P.H., Lemmetyinen H. Chem. Phys. Lett. 2001, 345, 213.

21. Efimov A., Tkatchenko N.V., Vainiotalo P., Lemmetyinen H. J. Porphyrins Phthalocyanines 2001, 5, 835.

22. Smith K.M., Goff D.A., Simpson D.J. J. Am. Chem. Soc. 1985, 107, 4946.

23. Johnson D.G., Svec W.A., Wasielewski M.R. Isr. J. Chem. 1988, 28, 193.

24. Helaja J., Tauber A.Y., Abel Y., Tkachenko N.V., Lemmetyinen H., Kilpeläinen I., Hynninen P.H. J. Chem. Soc., Perkin Trans. 1 1999, 2403.

25. Spiller W., Kliesch H., Wöhrle D., Hackbarth S., Röder B., Schnurpfeil G. J. Porphyrins Phthalocyanines 1998, 02, 145.

26. Kuznetsova N.A., Gretsova N.S., Derkacheva V.M., Mikhalenko S.A., Solov'eva L.I., Yuzhakova O.A., Kaliya O.L., Luk'yanets E.A. Russ. J. Gen. Chem. 2002, 72, 300.

27. Yamakoshi Y., Umezawa N., Ryu A., Arakane K., Miyata N., Goda Y., Masumizu T., Nagano T. J. Am. Chem. Soc. 2003, $125,12803$.

28. Michinobu T., Okoshi K., Murakami Y., Shigehara K., Ariga K., Nakanishi T. Langmuir 2013, 29, 5337.

29. Boyd P.D.W., Hodgson M.C., Rickard C.E.F., Oliver A.G., Chaker L., Brothers P.J., Bolskar R.D., Tham F.S., Reed C.A. J. Am. Chem. Soc. 1999, 121, 10487.

30. Trimpin S. J. Am. Soc. Mass Spectrom. 2016, $27,4$. 